УДК 37.035.6:371(477.8) “ҮIII / XІХ”

DOI:

Марія Багрій, кандидат філологічних наук, докторант ДВНЗ “Прикарпатський національний університет імені Василя Стефаника”

\title{
ОСВІТНЯ ТА ГРОМАДСЬКА ДІЯЛЬНІСТЬ ЗАХІДНОУКРАЇНСЬКИХ ПИСЬМЕННИЦЬ-ПЕДАГОГІВ (кінець ХІХ - 30-ті pp. ХХ ст.)
}

У статті відображено актуальні освітні та громадські проблеми та потреби украӥнського суспільства крізь призму діяльності західноукраӥнських письменниць-педагогів, та проаналізовано чинники виховання національно-свідомої особистості у творчості письменниць-педагогів Західної Украйни кінця ХІХ 30-ті рр. ХХст. Зображено організаторів жіночого руху на західноукрайнських землях, суперечності між традииійною, офіційною концепиією щцодо навчання та виховання та підходами, щуо брали за зразок західну педагогіку $i$ досвід європейської школи.

Ключові слова: освітня діяльність; громадська діяльність; феміністичний рух; наџіональна педагогіка; Західна Украӥна.

Jim. 13.

Mariya Bahriy, Ph.D.(Philology), Doctoral Student State Pedagogical University "Precarpathian Vasyl Stefanyk National University"

\section{EDUCATIONAL AND PUBLIC ACTIVITY OF WESTERN UKRAINIAN WRITTEN- PEDAGOGES (end of the XIX - 30ths years of century XX)}

The article presents the actual educational and public problems and needs of the Ukrainian society through the prism of the activities of Western Ukrainian writers-teachers, and analyzes the factors of education of a national conscious personality in the writers of Western Ukraine in the late 19th and 20th centuries. It depicts the organizers of the women's movement in the Western Ukrainian lands, the contradiction between the traditional, official concept of education, and approaches that have taken Western Western pedagogy and the experience of the European school.

It is worth noting that it was during this period of the formation of national pedagogy that feminist movement was actively manifested. The purpose of the activity of these feminist societies was to promote the Greek Catholic Church's prosperity, to support the poor girls of the Greek-Catholic faith, and the purpose of the "Women's Community of Bukovyna" was to raise the national consciousness, culture and welfare of the Ukrainian people, and raise the level of education of Ukrainian women. The activities of these societies were broadly cultural and educational and charitable and were carried out in the following directions: creation of children's preschool institutions, so-called burial grounds; organization of girls burs; arrangement of "courses of cut and sewing", "courses on the elimination of illiteracy", courses on the manufacture of products for folk motives; a collection and organization of exhibitions of folk arts and crafts; reading lectures and reports, arranging literary evenings, etc. in order to raise funds for charitable purposes; providing material assistance to orphans and poor girls, children.

An analysis of life and activity, literary works of writers and teachers gives us the opportunity to conclude that civic consciousness, patriotism, devotion to the interests of the people are inherent, first of all, by the authors themselves. Analyzing literary works of public and educational activities, we see that they are saturated with various educational situations, characters, views, actions of children who lived in the first half of the twentieth century in the territories of modern Western Ukraine.

Keywords: an educational activity; public activity; feminist movement; national pedagogy; Western Ukraine.

П остановка проблеми. Освітня та громадська діяльність західноукраїнських письменниць-педагогів кінця XIX-30-тих років XX ст., які працювали і творили у школах та різноманітних організаціях Західної України, $є$ достовірним джерелом інформації про розвиток шкільництва та громадських організацій в зазначений історичний період. Будівництво громадської та освітньо-виховної справ досліджуваного періоду вимагало ініціативних, відданих своїй справі людей, які б узяли керівництво цим процесом у свої руки, і засобів, що б забезпечили виконання поставлених завдань.

Мета дослідження - виокремити актуальні освітні та громадські потреби і проблеми Західної України кінця XIX - 30-ті pp. XX ст. у творчості тогочасних українських письменниць-педагогів.

Аналіз останніх досліджень і публікацій. Попри те, що західноукраїнські письменниціпедагоги у своїх організаціях і творах порушували актуальні питання навчання і виховання дітей та юнацтва, окремого грунтовного і цілісного дослідження цієї наукової проблеми не здійснено. 
Відображення актуальних освітніх та громадських потреб і проблем українського суспільства та виховання національно-свідомої особистості у творчості письменниць-педагогів Західної України кінця ХIX - 30-ті рр. XX ст. частково опрацьовано в працях Г. Білавич, С. Вдовича, Т. Завгородньої, В. Качкана, О. Любара, Л. Потапюка, Ф. Потушняка, М. Романюка, В. Яременка.

Виклад основного матеріалу. Варто зазначити, що саме у цей означений період становлення національної педагогіки активно проявив себе феміністичний рух. Активною учасницею цього руху була Софія Атанасівна Окуневська-Морачевська (1865 - 1926 рр.) українська громадська діячка, перша випускниця університету та жінка-лікар в Австро-Угорщині.

Організаторкоюжіночого рухуназахідноукраїнських землях вважається Кобринська Наталія Іванівна (1855 - 1920 рр.). Її творчість стояла біля витоків українського фемінізму, позитивно націленого не на руйнування, а на будівництво та творчість. Вона стала ініціатором першої української жіночої організації. “Перший вінок” заклав основи розвитку жіночих часописів, які редагували i видавали самі жінки. Він з'явився 1889 році у Львові за редакцією Олени Пчілки та Наталії Кобринської.

Втіленням в життя іiі ідей стало заснування першого “Товариства руських жінок” у грудні 1884 року. I як найбільший його здобуток “ альманах “Перший вінок” (1887 р.) за її редакцією та Олени Пілки. Із публікаціями тут, крім упорядниць, виступили Г. Барвінок, О. Грицай, Дніпрова Чайка, У. Кравченко, С. Окуневська, А. Павлик, К. Попович, М. Рошкевич, Леся Українка, О. Франко та ін. Альманах увійшов в історію української літератури як перша письменницька жіноча антологія [9, 517].

Заслуговує на увагу політична та громадська діяльність Олени Карпівни Левчанівської,яка активно займалася освітньою і громадською діяльністю: організовувала школи, співпрацювала у “Просвіті". У 1922 р. обрана від Волині до сенату Речі Посполитої, де гостро ставить питання захисту прав українського народу. Входила до комісії закордонних справ. Як член міжнародної жіночої Ліги миру і свободи виступала в Празі, Женеві, Парижі, захищаючи права українців у Польщі. У 1939 р. заарештована органами НКВС і депортована в Казахстан.

На нашу думку, цікавим $є$ постать Михайлини (Михайлина-Марія) Михайлівни Рошкевич. Народні пісні, зібрані нею I. Франко використав у дослідженні “Жіноча недоля в руських піснях народних” (1883 р.). Про ці замальовки із життя I. Франко писав: “. ...Шкіц панни Міні дуже тут усім подобався і швидко буде надрукований із похвальною заміткою. Павлик посилає їй письмо від себе, “ а я замічу тільки, що в неї видно, коли ще не талант письменницький, то принаймні величезну силу обсервації, яка для всякого писателя повістей перша і найважніша річ. Як би панна Міня (чого від серця бажаю) взялася писати більше подібних шкіців, а при тім читала другі взірцеві повісті (Золя, Толстого, Решетнікова, Нечуя), то з неї могла б виробитися дуже реальна й хороша письменниця" $[13,22]$.

Однак, попри такої оцінки та протести авторки, іiі матеріал "Кума з кумою" появилася в "Молоті” як “дуже цікавий образок з життя жінок у Лолині" 3 прихильною оцінкою від видавництва, яке побажало, щоб “молода авторка не покидала й надалі подібної праці”.

Не відставала від брата М. Павлика у своїй громадсько-просвітнийькій діяльності й Анна Павлик (1855 - 1928) - українська громадськокультурна діячка і письменниця, активна учасниця жіночого руху в Галичині. Книжки та журнали, що їх надсилав їй брат Михайло, розповсюджувала серед селян Косова, через що зазнавала переслідувань з боку місцевої влади [3, 379].

Значне місце займає й Ольга Юліанівна Кобилянська (1863 - 1942 рр.). Так, знаходячись в 1894 році біля витоків створення "Товариства руських жінок на Буковині”, О. Кобилянська обгрунтувала мету цього руху, порушила питання про тяжке становище жінки "середньої верстви", активно виступила за рівноправність жінки й чоловіка, за право жінки на гідне життя.

Активним членом і засновником перших жіночих товариств у Станіславові, Коломиї стала Олена Львівна Кисілевська (1869 - 1956) українська письменниця, журналістка, редактор і видавець, громадсько-політична та культурноосвітня діячка, яка працювала у львівській жіночій громаді. Перейнявшись ще замолоду ідеями Наталії Кобринської, розширила погляд першої на жіноче питання, доклала багато зусиль для розкриття духовного світу жінки та іiі ролі у вихованні молодого покоління в патріотичному дусі.

3-під іï пера вийшли сотні статей, збірки, що мають не лише художню, а й соціальногромадську цінність, зокрема, “Українське жіноцтво в старовині”, “Олена Кульчицька”, “Як вести працю в жіночих гуртках”, “Самовиховання” (кінець 1920-х років). Праці цієї тематики друкувалися також на сторінках тоді відомих періодичних видань як “Світ", “Ілюстрована Україна”, “Молода Україна”, “Український голос", “Нова хата". 


\section{ОСВІТНЯ ТАГРОМАДСЬКАДІЯЛЬНІСТЬЗАХІДНОУКРАЇНСЬКИХ ПИСЬМЕННИЦЬ-ПЕДАГОГІВ}

(кінець XIX - 30-ті рp. XX ст.)

Діячкою жіночого руху, авторкою місцевих часописів була Ольга Захарівна Гузар (1885 - 1945 рр.), яка була багаторічним головою товариства "Жіноча громада Буковини" і активним членом (певний час керівником) жіночого релігійнодоброчинного товариства “Мироносиці”. Обидва товариства були засновані в Чернівцях за сприяння українського товариства "Руська Бесіда”, що вважається першою іскрою національної свідомості та національного відродження українців; товариство "Мироносиці" було засноване в 1886 році, “Жіноча громада” - в 1906 році.

Метою діяльності цих товариства було сприяння процвітанню греко-католицької церкви, підтримка бідних дівчат греко-католицького віровизнання, а метою діяльності товариства “Жіноча громада Буковини” було піднесення національної свідомості, культури та добробуту українського народу, виховання і піднесення рівня освіти українських жінок. Діяльність цих товариств мала загалом культурнопросвітницький та доброчинний характер і велась в напрямах: створення дитячих дошкільних закладів, так званих “захоронок”; організація дівчачих бурс; влаштування “курсів крою та шиття”, “курсів 3 подолання неписьменності”, курсів 3 виготовлення виробів за народними мотивами; збирання та організацією виставок народного художньо-ужиткового мистецтва; читання лекцій і доповідей, влаштування літературних вечорів та ін. з метою збору коштів на благодійні цілі; надання матеріальної допомоги сиротам та вбогим дівчатам, дітям. Товариство “Жіноча громада” розширювало свою діяльність на села та містечка Буковини і мала 14 філій у провінції [5].

Визначальною подією стало створення у Галичині організація Союзу українок. В 1922 року ii друкованим органом став “Жіночий вістник”, згодом тематична сторінка "Громадського вісника”, редактором якого була Мілена Рудницька, авторами - О. Залізнякова, Н. Суровцева, M. Струтинська. Жіночий кооператив "Українське народне мистецтво" заснував журнал для “плекання домашньої культури" "Нову хату”. В 1925 року у Коломиї виходив часопис “Жіноча доля”, а згодом “Жіноча воля”, “Світ молоді”, “Жіночий голос”, “Українська господиня”, “Жінка”. Замість закритою польської владою “Жінки” почав виходити двотижневик “Громадянка", місячник "Українка”, “Світ українки" $[6,193]$.

Однією з ідеологів українського жіночого руху Західної України та його провідних діячок у 1920
- 1930-х рр. вважається Мілена Іванівна Рудницька, у заміжжі Лисяк (1892 - 1976 рр.) українська громадсько-політична діячка, журналістка, письменниця, учителька середніх шкіл, голова центральної управи Союзу Українок. До доби "Розстріляного відродження" варто віднести перекладача, актрису, педагога дружину письменника Клима Поліщука “ Галину Іванівну Мневську (літературний псевдонім Галина Орлівна; 1895 - 1955 рр.).

Аналізуючи теоретичні основи навчання i виховання дітей та молоді досліджуваного періоду в творах письменниць-педагогів не можна не згадати яскраву сторінку в історії української педагогіки, що пов'язана з освітньою діяльністю і педагогічними поглядами Лесі Українки (Лариси Петрівни Косач). I хоча поетеса не залишила по собі грунтовних педагогічних праць, які б містили розгорнутий та систематичний виклад педагогічних думок чи авторського погляду, однак 3 певненістю можна стверджувати, що освітньовиховна діяльність видатної української оповідачки розвивалася за продуманими педагогічними принципами.

Так, перша педагогічна практика авторки навчання і виховання молодших рідних та двоюрідних братів і сестер (у сім’ї Косачів жив молодший син М. Драгоманова Зоря (Свєтозар); деякий час - тітка Саша (О.А. КосачШимановська) 3 синами Антоном і Павлом). Отже, педагогічна діяльність письменниці розпочалася саме з “родинної педагогіки”. У своїй освітянській діяльності Л. Українка була дуже відповідальна: “цьому передувало шкільне вивчення практики роботи школи, гімназії, тривалі консультації 3 народними вчителями, прогресивними представниками української громади; ознайомлення з різними програмовими джерелами та публікаціями науково-методичного спрямування" [10, 49].

Практичним втіленням цієї діяльності є укладання збірок “Дитячі ігри, пісні та казки Ковельського-Луцького і Новгород-Волинського повітів Волинської губерніи”' (1903р.), “Народні мелодії з голосу Лесі Українки”, написання творів для дітей (цикл поезій під назвою “Дитяче”). Доробок Л. Українки, що носить просвітницький характер $\epsilon$ не тільки в художніх творах. Авторка звертається до всієї громади українських педагогів та вчителів із закликами до необхідності забезпечити підготовку дітей до життя на засадах принципів широкого пізнання навколишнього світу; пробудження i розвитку національної самосвідомості та виховання учнів в дусі поваги й дружби між народами; виховання у дитини 
високої моральності, й у своїх публіцистичних творах, рецензіях та відгуках.

Варто зауважити, що саме завдяки матері (Олени Пчілки) Л. Українка любила свій край і цікавилась його фольклором, етнографією та педагогікою. Адже Олена Пчілка вперше сформувала концепцію “Молодої України”, в основі якої була національна ідея, яку освітянка запозичала у романтиків (одухотворена природа та дитинство як повноцінна чи навіть ідеальна фаза людського розвитку, до якої вже ніколи не повернеться дорослий).

Отже, письменницько-видавнича та педагогічна діяльність Олени Пчілки пронизана глибоким іiі переконанням, що дитину необхідно сприймати як повноцінну особистість 3 власним, відмінним від дорослих внутрішнім світом. Така позиція прослідковується у більшості їі творів; перекладах текстів дитячої літератури з іноземних мов на українську; підборі віршів, оповідань, казок узбірки інших українських письменників.

Яскравим прикладом педагогічного доробку Л. Українки став написаний нею підручник “Стародавня історія східних народів”, над яким авторка працювала понад 20 років. У підручнику навчальний матеріал подається логічно. А кожна 3 шести частин книги починається описом природного оточення певного народу, оглядом його політичної та соціально-економічної історії. Після усвідомлення даної інформації пропонується розповідь про звичаї, вірування, побут, традиції. Вагоме місце в підручнику займає аналіз джерел. Жоден історичний факт Леся Українка не згадує без точного посилання на джерело, що підтверджує наукову принциповість. Серед важливих джерел пізнання історії народу автор називає мову і всі види словесної творчості [1].

Просвітницька діяльність письменниці найяскравіше проявилася у іï перекладацькій роботі. Перші, ще учнівські спроби авторки (під керівництвом матері Олени Пчілки) - це “Вечорниці на хуторі під Диканькою”. До книжки увійшли "Передмова Панька Рудого", “Запропаща грамата” і “Зачароване місце”. Пізніше переклала українською мовою уривок із поеми А. Міцкевича "Конрад Валленрод" - "Вілія, що наші струмочки приймає” (1885р.), третю і п’ять рядків четвертої пісні Гомерової “Одіссеї” (1888 р.). У 1888 - 1890 рр. переклала 92 вірші, що увійшли до книжки "Всесвітні твори. Книга пісень Гайнріха Гайне. Переклад Лесі Українки та Максима Славинського, Львів, 1892” [12].

Варто зауважити, що Леся Українка не писала педагогічних трактатів 3 методики навчання та виховання, організації навчально-виховного процесу. Проте завдяки своїй сім'ї, оточенню, в якому вона зростала та виховувалась, упродовж свого життя творила свою педагогічну систему, утверджувала принципи педагогіки життя, родинної народної педагогіки.

Інша представниця письменників-педагогів аналізованого періоду - Уляна Кравченко (1860 1947 рр.). Призначення поета, на іiі думку, боротися за правду, за волю, за кращу долю для свого народу. Безумовно, авторку можна назвати прогресивним педагогом, адже процвітання рідного краю вона пов'язувала 3 вихованням майбутніх поколінь свідомих громадян, патріотів, борців за справедливий устрій та національні цінності.

Багато творів У. Кравченко, поетичних i прозових, пройняті щирою любов’ю, турботою про долю школярів, закликом до вчительської громади відводити центральне місце дитині, формуванню iii моральних якостей, творчих здібностей, розвиткові інтелектуального, духовного потенціалу. Педагог всі свої знання, переконання, талант намагалася передати дітям. "Мило мені з дітьми в класі, мовби нічого поза нею в світі не існувало. Добре мені в моїм новім житті, весело на дорозі нових обов'язків, усміхом милим і поглядом щирозолотим принаджують мене діти до себе" [4, 314].

У контексті нашого дослідження цікавою $є$ повість “Спогади вчительки”. Адже саме цей твір письменниці стало джерелом інформації про шкільництво Галичини на рубежі XIX - XX століття. У цьому художньому творі авторка описує систему навчання у школі в місті Бібці, що зводилася в основному до бездумного заучування і запису текстів напам'ять. При цьому шкільні вчителі зовсім не переймалися проблемами навчання дітей, полишаючи їх часто на старших учнів, які тримали молодших школярів у страху.

Показовим є такі персонажі повісті, як панна Маня, Гордієнко, управитель школи. Уже за перший рік навчання діти з їі класу, за висновком інспектора, досягли найкращих успіхів у навчанні, тому що весь час вона витрачала на навчання дітей, не беручи участі в постановках беззмістовних п'єс, у вечорницях. Автор повісті намагається і Гордієнка “залучити до корисної справи, відучити держати для громадян, а дохід повернути на бідну дітвору”, робити для громади “щось, що є гуманне” [4, 33].

У цьому контексті, яскравою представницею “народної педагогіки” можна назвати К. Малицьку (1872 - 1947 рр.). Адже лейтмотивом її художньолітературних творів $є$ інтенція про першочергове 


\section{ОСВІТНЯ ТАГРОМАДСЬКАДІЯЛЬНІСТЬЗАХІДНОУКРАЇНСЬКИХ ПИСЬМЕННИЦЬ-ПЕДАГОГІВ}

(кінець XIX-30-ті pp. XX ст.)

значення батьків як перших педагогів дитини. Звичайно, передусім мова йде про матерів. У своїх прозових текстах образ матері письменниця представляла у різних іпостасях: це могли бути жінки, які патріотизм роблять осердям виховання, чи навпаки - прищеплюють споживацьку філософію буття (“Мати”); які своєю поведінкою утверджують станову нерівність (“Мур”);які ізолюють дітей від буденних клопотів, схвалюючи їхню зверхність до решти (“В залізниці”); які вихваляються дітьми, не помічаючи їхні ганебні вчинки (“У церкві”, “Ї̈̈ син”); які принижують дитину і використовують эї як безкоштовну робочу силу, не дозволяючи розвиватися (“При записі”, “Мужицька дитина"); які передають ідеї соціальної справедливості як найвищу чесноту (“Великодні квіти”); які зневажають літніх людей, забуваючи про подібне власне майбутнє завдяки таким прикладам (“За провини батьків”); які декларують одне, а діють всупереч власним постулатам, навчаючи дітей лицемірству та подвійним стандартам (“Гріх").

Гімназист Борис (“Малий гуцулик”К. Малицької) 3 дитинства прагнув учитися. Закінчивши школу в селі, навчається в гімназії, заробляючи репетиторством. Автор знайомить нас із героєм, коли він намагається переночувати у собачій буді, бо склалося так, що через заметілі не прийшла посилка з села, а родина, у якій Борис навчав дітей, виїхала з міста. Однак це не змінює палкого бажання хлопця вчитися, щоб приносити користь рідній країні й народові: “у будинку родини Дормутів, окруження в старім, витертім мундурку, лиш марне личко зарожевіло тепер одушевленням, а ясні очі гляділи десь далеко вперед, немов усміхалися до того великого світла, за котрим рвалася молода душа, щоб, спохвативши його, повною жменею розкинути відтак серед темряви рідної країни...” $[7,59]$.

Чітку громадянську позицію виявляє головний герой оповідання К. Малицької “Малий гуцулик” Данилко, який гордий $з$ того, що є українцем, i впевнений у неправдивості слів “панів з міста", що "ті русини ні історії, ні літератури не мають". Хлопчик чув народні пісні, в яких оспівуються герої славної минувшини, “а той панич, що є тепер в єгомостя, має стільки книжок і читає з них поруськи таки людям" $[7,16]$.

Данилко має лицарську вдачу (без страху кинувся вниз, де “шуміло й клекотіло, як у справдішній чортівській печері”, щоб підняти капелюшок панночки); виявляє мистецькі здібності, майстерно вирізаючи топірці; не подитячому розсудливий, тому на висловлювання, якими пани ображають односельців, “його густі брови грізно здвигаються над темними очима, губи затискаються до крові”, а “в його серці накипає жаль до цих ось людей, що прийшли на його рідну землю зневажати іiі синів" $[7,15]$.

Малий гуцулик знайшов свій засіб виховного впливу на пихатих панів: віддав гроші, які йому заплатили, сказавши, що не візьме їх від тих, хто зневажає його народ; подарував панові топірець, щоб у місті бачили, що гуцули талановиті й уміють створити прекрасні речі. Героїня оповідання К. Малицької “Задля рідного слова” Неоніла, одинадцятирічна дівчинка, зрікається “не одної приємності в житті” і погоджується їхати вчитися до Львова. Вона пише у листі батькові: “Я буду вчитися много і пильно в своїй рідній мові, щоб не глумилися 3 нас вороги. Я хочу бути розумною українкою, хочу працювати". Слід зазначити, що джерелом такого патріотизму була національно свідома і національно орієнтована сім'я Неоніли. Зокрема, правильне рішення дівчинці допоміг прийняти старший брат Роман, переконавши сестру, що “лише в науці, у спільному труді і пожертвуванні одиниць наша сила і краща будучність" [7, 12].

Привертає увагу педагогічна діяльність М. Підгірянки (Марія Омелянівна ЛенертДомбровська) (1881 - 1963 рр.), яка більшість творів написала про дітей і для дітей. Однак поетеса не була лише дитячою письменницею. Авторка писала багато “актуальних" патріотичних, “виховних” віршів. Наприклад, перші iï збірки (“Відгуки душі” (1908р.), “Краплини крові” та ін.).

Отже, літературні твори М. Підгірянки художньо-педагогічний феномен національної культури, оскільки вони виразно позначені індивідуальною творчою манерою, містять виховні концепти, що майстерно були виражені через різноманітні художні прийоми. Авторка щедро використовує фольклорні мотиви. Саме тому їі вірші відрізняються особливою ніжністю та легкістю, нагадуючи при читанні українські народні пісні. Творчість поетеси - то справжня материнська енциклопедія, на якій виховувалися і виховуються цілі покоління.

Дуже часто зі сторінок художніх книг письменників-педагогів лунає заклик до учнів щодо необхідності здобуття освіти заради служіння українському народові. Так, герой казки “Гуцулик” В.Жуковецької, не злякавшись ні лісу темного, ні дороги далекої, ні урвищ глибоких, ні ведмедя страшного, поспішає до школи. "Коби скорше ліс минути, то вже можна в школі бути, і молитву відповісти, та у лавці чемно сісти" $[2,15]$.

Перечитуючи казки, оповідання, повісті 


\section{ОСВІТНЯ ТАГРОМАДСЬКА ДІЯЛЬНІСТЬЗАХІДНОУКРӒ̈НСЬКИХ ПИСЫМЕННИЦЬ-ПЕДАГОГІВ}

(кінець XIX-30-ті pp. XX ст.)

О. Цегельської, пересвідчуємося в тому, що в цей історичний період в пошані були такі родинні цінності, як спільність духовних інтересів, гармонія стосунків поколінь, піклування про батьків і старших у сім’ї, пошана до предків, сімейна злагода. Маленька Орися (оповідання “За здоров'ячко мамусі”) з нетерпінням чекає маминого дня. Вона підготувала подарунки для матусі, вивчила віршика. Вставши раненько, Орися "встає $з$ ліжечка і босими ніжками, на пальчиках, щоб не збудити мами, йде до вітальні““ $[11,40]$, щоб помолитися перед іконою Божої Матері за здоров'ячко мамусі.

Герой оповідання “Дмитрунь і його ножик”, граючись татовим ножиком, пошкодив щепку яблуні у сусідському саду. Татко не сварив сина, лиш лагідно пояснив йому: якщо пошкодити деревце, то воно вже не виросте і не буде родити яблучка. Дмитрунь уважно слухав і все зрозумів. А через деякий час татко 3 сином поїхали до знайомого садівника, привезли інше молоде деревце і посадили. “Нову щепу Дмитрунь доглядав, підливав і щиро бажав, щоб вона прийнялась, росла" [8, 22].

Однією з характерних ознак української сім’і $\epsilon$ дотримання народних традицій. 3 оповідань Олени Цегельської дізнаємося про звичаї українців, які збереглися і в еміграції. Так, мама розповідає Галюсі і Юрчикові (оповідання "На Святий Вечір”), “як то там, в Україні, святкували” $[11,28]$.

Наприклад, про те, що на Святий Вечір повинно бути всіх за святковим столом до пари. “А як не було до пари своїх, домашніх, то запрошували i чужих - чи сирітку, чи когось такого, що не мав своєї хати або родини" $[11,28]$.

У родині Задорожних в автомобільній катастрофі загинув батько, а на святковому столі “була ще одна тарілка, цілком чиста, неторкнена... Біля тарілки була і ложка, і виделка, і ніж, і склянка, і серветка збоку. А перед тарілкою горіла свічечка, перев'язана синьо-жовтою стьожечкою. I стояло там крісло, на якому ніхто не сидів” $[11,31]$.

У сім’ї маленької Орисі, героїні оповідання “За здоров'ячко мамусі”, у час воєнного лихоліття склалася своя традиція. Чудотворна ікона Почаївської Матері Божої вберігала родину в роки війни “від нещастя, від каліцтва, від смерти” [8, 38$]$.

Мама розповіла Орисі, що в роки війни вони були в Німеччині. Коли літаки скидали бомби, руйнувалися будинки, гинули люди. "Хто міг, утікав i ховався під землею. Але ми не мали де сховатися. Тоді ми виносили в сад ікону Почаївської Матері Божої, ставали перед нею на коліна і молилися" $[8,38]$.
Відтоді кожної суботи ввечері вся родина збирається у вітальні, де на покуті, прибрана квітами й рушниками, висить ця чудотворна ікона. "Мама засвічує лямпадку, всі стають на коліна і голосно повторюють за татом слова молитви. Дякують Матінці Божій, що спасла їх від смерти. Дякують, що так щасливо і спокійно можугь тепер жити" $[8,38]$.

Варто зауважити, що у літературних творах О. Цегельської задіяний надзвичайно сильний морально-релігійний компонент виховання. Так, маленькі герої демонструють у своїх вчинках любов до рідних, близьких, а часом і зовсім до незнайомих людей, вислухати людину і допомогти у скрутній ситуації, повагу до людей старшого покоління, вміння перейнятися чужими проблемами, здатність жертвувати собою заради родини.

Наприклад, п’ятирічна Марійка (оповідання “Гість із далекої країни”), щиро співчуває маленькій Тані, що прилетіла до своєї бабусі з далекої Америки, бо у неї померли батьки. Дізнавшись, що дівчинка не знає української мови, взялася навчити іiї розмовляти "по-нашому, порідному" $[8,26]$.

Оскільки події відбувалися перед Різдвом, то “Маруся показувала пальчиком якусь річ i називала іiі: - Це “ялинка", а то “вертеп”, а он “малий Ісусик” $[8,26]$.

У результаті такої науки першими для Тані стали "слова про Різдво, а першою піснею стала колядка" [8,26]. I хоч дівчинка повторяла слова смішно і незрозуміло, маленька “вчителька" не сміялася, пам’ятаючи, що і “в садочку пані вчителька не сміялася також 3 нікого, лиш лагідно повчала, як говорити" [8,27]. Дівчатка заколядували “Бог предвічний народився”. Таня “розвеселилася, розщебеталася”. Вона “вже не почувала себе сиріткою. Їй стало так тепло на серденьку, немов серед найближчої родини, а добра Маруся була для неї немов рідна сестричка" $[8,27]$.

Коли школярці Галі (оповідання “Перший раз до школи”) довелося самій іти до школи, коли їй були сумно і трохи страшно, бо не було поруч ні мами, ні татка, ні пані Гармаш, як це бувало зазвичай, ій на допомогу прийшло твоє старших дівчаток-школярок. Вони підбігли до дівчинки, розрадили, заспокоїли, а тоді з “обох боків ухопили за руки і то на одній нозі, то на двох, то навіть піднявши в повітря, понесли ії між собою, легку, мов пір'їнка" $[8,45]$.

А вчителька панна Зіновія, до якої підвели дівчатка нову школярку, взяла іiі за руку і повела в клас. “А ця рука панни вчительки була така ніжна, 


\section{ОСВІТНЯ ТАГРОМАДСЬКА ДІЯЛЬНІСТЬ ЗАХІДНОУКРАЇНСЬКИХ ПИСЬМЕННИЦЬ-ПЕДАГОГІВ}

(кінець XIX - 30-ті pp. XX ст.)

така тепла і ласкава, немов рука рідної матусі" $[8,46]$.

Характер стосунків між сусідами зобразила О. Цегельська у казці “В біді пізнати приятеля”. Під час лісової пожежі багатенька родина Хом'яка встигла врятувати все своє добро. Коли ж знайомий Заєць, у якого захворіла донечка Яся і який нічого не встиг прихопити з собою, попросив притулку, поки біда минеться, у Хом'яка і Хом'ячихи знайшлося багато відмовок: нірка завалена клунками, родина Зайців не запросила Хом'яків на обід $з$ приводу народження сина Яця. Як з'ясувалося, Хом'ячиха тільки шукала слушного часу, щоб помститися Зайцям. Вона злорадно посміхнулася і пішла готувати гарячий обід. “А бідна Зайчиха пригортала до грудей хворе дитятко й заливалася гіркими сльозами” $[8,14]$.

Однак допомогти Зайцям охоче погодилася Їжачиха, хоч близького знайомства між родинами не було. Їжак низько вклонився Зайцям, запрошуючи до хати. Хвору Ясю поклали у ліжечко, дали гарячого чаю з заячої капусти, від чого їй відразу полегшало. Їжак розповів, що вони минулого року теж зазнали лиха, коли повінь залила хату і потопила всі припаси. Заєць зробив висновок, що в "нещасті, в недолі звичайно той тебе порятує, хто сам біди зазнав” $[11,16]$.

Загалом усі твори О. Цегельської мають одну визначальну рису: вони переповлені любов'ю до дитини. В оповіданні "Новорічні побажання", наприклад, автор так описує маленького колядника: “Часом буває, що вже завидна сусідське малятко, так рочків три-чотири, бреде само снігом до найближчої хати. У великих теплих чобітках, у татовій смушковій шапці, що з-під неї і оченят не видно” $[11,35]$. Після побажань і пригощань, “буває, сусідка бере малятко на руки i, щоб не мусіло назад брести снігом, відносить його додому" $[11,36]$.

Висновки. Аналіз життя і діяльності, літературних творів письменниць-педагогів надає нам можливість зробити висновок, що громадянська свідомість, патріотизм, відданість інтересам народу властиві, в першу чергу, самим авторкам. Аналізуючи літературні твори громадську та просвітницьку діяльність, ми бачимо, що вони насичені різноманітними виховними ситуаціями, характерами, поглядами, вчинками дітей, які жили в першій половині XX століття на територіях сучасної Західної України.

\section{ЛІТЕРАТУРА}

1. Валентій Л.В. Освітня діяльність Лесі Українки. Вісник Чернігівського національного педагогічного університету. Педагогічні науки. 2013. Вип. 108.1.
2. Жуковецька В. Служи Україні : оповідання та казки: для молодшого шкільного віку / упоряд. та автор передмови С. Кухта. - Київ, 1994. 46 с.

3. Історія української літератури. Кінець ХIX - початок XX ст.: У 2 кн.: Підручник / За ред. проф. О.Д. Гнідан. Київ, 2005. 624 с.

4. Кравченко Уляна. Вибрані твори. Львів, $1996.459 \mathrm{c}$.

5. Лекції з історії світової та вітчизняної культури - Яртися: Національно культурне відродження у Галичині. URL: http: // slv.com.ua/ bookz/210/7989.html

6. Любар О.О., Стельмахович М.Г., Федоренко Д.Т. Історія української школи і педагогіки : навч. посіб. Київ, 2006. 447 с.

7. Малицька К. І. Малі герої. Львів, 1991. 61 с.

8. Перед божими яслами: різдвяні легенди українських письменників / укладач Зоряна Живка. Львів, 2009. (Серія “Різдвяна Антологія").

9. Сірополко С. Історія освіти в Україні. Київ, $2001.912 \mathrm{c}$.

10. Струманський В. П. Педагогічні погляди Лесі Українки. Початкова школа. 1996. № 2.

11. Цегельська О. Петрусева повість. Оповідання. Вид-во "Нашим дітям" ОПДЛ, 1950. 39 с.

12. Чапленко Н. Наші сучасниці - короткі біографії. Українка в світі. 1979. № 1. С. 30-31.

13. Франко І. Педагогічні статті і висловлювання. Київ, 1960.59 с.

\section{REFERENCES}

1. Valenty, L.V. (2013). Osvitnya diyalnist Lesi Ukrayinky [Lesia Ukrainka's Educational Activities]. Visnyk of Chernihiv National Pedagogical University. Pedagogical sciences. Issue 108.1. [in Ukrainian].

2. Zhukovetska, V. (1994). Sluzhy Ukrayini [Serving Ukraine: stories and fairy tales: for junior school age]. (Ed.). S. Kuhta. Kyiv, 46 p. [in Ukrainian].

3. Istoriya ukrayinskoyi literatury (2005). [History of Ukrainian literature]. The end of the nineteenth and early twentieth centuries. At the 2 nd volume: Textbook. (Ed.). O.D. Gnidan. Kyiv, 624 p. [in Ukrainian].

4. Kravchenko Ulyana (1996). Vybrani tvory [Selected Works]. Lviv, 459 p. [in Ukrainian].

5. Lektsiyi $z$ istoriyi svitovoyi ta vitchyznyanoyi kultury [Lectures on the history of world and national culture]. [Electronic resource]. Available at: http: // slv.com.ua/bookz/210/7989.html [in Ukrainian].

6. Lyubar, O. O., Stelmakhovich, M.G. \& Fedorenko, D.T. (2006). Istoriya ukrayinskoyi shkoly i pedahohiky : navch. Posib. [History of Ukrainian School and Pedagogy: Teach. Manual]. Kyiv, 447 p. [in Ukrainian]. 


\section{ROLEOF STUDENTS'ACADEMICMOTIVATIONIN FOREIGN LANGUAGEACQUISITION INAGRO-TECHNICALHIGHEREDUCATIONINSTITUTIONS}

7. Malitskaya, K. I. (1991). Mali heroyi [Small Characters]. Lviv, 61 p. [in Ukrainian].

8. Pered bozhymy yaslamy: rizdvyani lehendy ukrayinskykh pysmennykiv (2009). [Before the Godfather: the Christmas legends of Ukrainian writers]. (Ed.).Z. Zyvka. Lviv. (Series "Christmas Anthology"). [in Ukrainian].

9. Siropolkko, S. (2001). Istoriya osvity $v$ Ukrayini [History of education in Ukraine]. Kyiv, 912 p. [in Ukrainian].

10. Strumansky, V. (1996). Pedahohichni pohlyady
Lesi Ukrayinky [Pedagogical views of Lesya Ukrainka]. Primary school. No. 2. [in Ukrainian].

11. Tsegelskaya, O. (1950). Petruseva povist. Opovidannya [Petrushev's story. Stories]. View "Our children" OPDL, 39 p. [in Ukrainian].

12. Chaplenko, N. (1997). Nashi suchasnytsi-korotki biohrafiyi [Our contemporaries - short biographies]. Ukrainka in the world. No. 1, pp. 30-31. [in Ukrainian].

13. Franco, I. (1960). Pedahohichni statti $i$ vyslovlyuvannya [Pedagogical articles and statements]. Kyiv, 59 p. [in Ukrainian].

Стаття надійшла до редакції 16.04.2019

УДК 378.094+37.091.33:8111.111

DOI:

Zoryana Dzyubata, Ph.D.(Pedagogy), Senior Lecturer of the Humanities Disciplines Department of Separate Subdivision of National University of Life and Environmental Sciences of Ukraine "Berezhany Agrotechnical Institute"

\section{ROLE OF THE STUDENTS'ACADEMIC MOTIVATION IN FOREIGN LANGUAGE ACQUISITION IN AGRO-TECHNICAL HIGHER EDUCATION INSTITUTIONS}

The paper covers the problem of teaching a foreign language and skills of effective communication in the learning environment of an agro-technical institute / university in Ukraine. The current state of the students' language proficiency and communication skills has been found to be insufficient. The importance of obtaining skills of effective communication as a part of agrarian's professional competence has been substantiated. Reinforcement of the students 'academic motivation is considered to be essential for learning and practicing skills of effective communication in the process of foreign language acquisition at an agro-technical university. Thus, the main motivational constructs (beliefs / perceptions, goals, values, and intrinsic versus extrinsic motivation) has been related to foreign language acquisition and the effective strategies that lecturers can apply to engage students in an ESL / ESP class has been suggested. They include clear goals to assure the students' communication skills for obtaining professional knowledge and future employability, students-centered classroom environment, proper material content and its professional specification applied together with a communicative language teaching approach.

Keywords: academic motivation; agro-technical higher education institutions; communication skills; foreign language acquisition; future agrarians.

Ref. 12.

Зоряна Дзюбата, кандидат педагогічних наук, старший викладач кафедри гуманітарних дисичилін ВП НУБіП Украйни “Бережанський агротехнічний інститут”

\section{РОЛЬ МОТИВАЦІЇ У ФОРМУВАННІ ІНШОМОВНОЇ КОМУНІКАТИВНОЇ КОМПЕТЕНТНОСТІ СТУДЕНТІВ АГРОТЕХНІЧНИХ ВИЩИХ НАВЧАЛЬНИХ ЗАКЛАДІВ ОСВІТИ}

У статті розглянуто проблему вивчення іноземної.мови і практики умінь ефективної комунікаціїу навчальному середовищі сучасного агротехнічного інституту чи університету в Україні. Сучасний стан рівня володіння іноземною мовою і комунікативними уміннями студентів агротехнічних закладів освіти виявився не достатнім. Обтрунтовано важсливість набуття умінь ефективної комунікаціїяк обов 'язкової складової професійної компетентності аграрника. Покращення навчальної мотивачії студентів сприяс формуванню комунікативних умінь студентів. Таким чином, досліджено співвідношення основних мотиваційних компонентів (сприйняття, иілі, ијіноості, внутрішня $і$ зовнішня мотивація) з прочессом вивчення іноземної мови і виведено ефективні стратегії формування комунікативних умінь студентів у прочесі вивчення загального курсу іноземної мови та іноземної мови за професійним спрямуванням в агротехнічних вищих навчальних закладах, а саме: постановка чітких иілей в плані формування комунікативних умінь необхідних для набуття професійних знань і майбутньої професійної діяльності, створення особистісно-спрямованого навчального середовища, предметно-мовне навчання з врахуванням інтересів та потреб відповідної групи студентів.

Ключові слова: навчальна мотивація; агротехнічні вищі навчальні заклади освіти; процес вивчення іноземної мови; комунікативні уміння; майбутні аграрники.

I

ntroduction. Skills of effective communication

both in L1 and L2 are considered to be a

significant part of an agrarian's professional

competence aimed at providing effective performance of their professional tasks, high mobility and flexibility required by modern market conditions, constant 